\title{
PENGABDIAN PADA MASYARAKAT: SOLUSI UKM INTIP DALAM MENINGKATKAN PRODUKSI SAAT MUSIM HUJAN
}

\author{
Arif Setyo Nugroho ${ }^{1)}$, Aris Teguh Rahayu ${ }^{2)}$ \\ Sekolah Tinggi Teknologi Warga Surakarta \\ ${ }^{1)}$ Program Studi Teknik Mesin, \\ ${ }^{2)}$ Program Studi Teknik Elektronika \\ ${ }^{1)}$ arif.snug@yahoo.co.id; arifsnatw@gmail.com; arifsetyon@atw.ac.id
}

\begin{abstract}
Abstrak
Salah satu makanan cemilan khas dari nasi adalah intip, jika menanak nasi menggunakan kendil atau panci didasar kendil biasanya terdapat kerak. Kerak nasi disebut intip. Cemilan intip sekarang banyak rasa, rasa orisini, rasa manis atau rasa asin, tetapi intip yang mempunyai rasa khas adalah intip dari desa Gawan, Kecamatan Tanon, Kabupaten Sragen. Intip dikerjakan ibu - ibu yang tergabung dalam BUMDes Soyo Ngremboko. Dalam musim hujan terjadi kendala dalam produksi, intip tidak bisa kering secara maksimal seperti ketika dikeringkan dengan sinar matahari, mengakibatkan intip tersebut rusak berjamur, akibatnya produksi menurun disaat permintaan meningkat. Solusi yang ditawarkan adalah mesin pengering dengan sistem turbulent flow, berbahan bakar LPG. Pengering intip memiliki ukuran panjang $120 \mathrm{~cm}$ x lebar $50 \mathrm{~cm}$ dan tinggi $150 \mathrm{~cm}$.Dilengkapi dengan loyang berlubang untuk tempat intip . Sumber panas berasal dari LPG, dilengkapi pengatur dan pembaca temperatur, flow valve solenoid dipasang di saluran gas LPG.Distribusi panas biar rata dibantu blower 2 inch, Pengeringan intip membutuhkan waktu selama 4 jam.
\end{abstract}

Kata kunci : Intip, musim hujan, produksi,pengering, LPG

\begin{abstract}
One of the typical snack foods from rice is intip, if you cook rice using a jug or a pot on the bottom of the kendil there is usually a crust. The rice crust is called a intip. The intip snack now has many flavors, original flavors, sweet or salty tastes, but the peek which has a distinctive taste is the peek from Gawan Village, Tanon District, Sragen Regency. Peek was done by women who are members of BUMDes Soyo Ngremboko. In the rainy season there are constraints in production, the peephole cannot dry optimally, such as when it is dried in the sun, causing the peephole to become moldy, as a result production decreases when demand increases. The solution offered is a dryer with a turbulent flow system, fueled by LPG. The peephole dryer is $120 \mathrm{~cm}$ long $x 50 \mathrm{~cm}$ wide and $150 \mathrm{~cm}$ high. It is equipped with a perforated baking sheet for a peephole. The heat source comes from LPG, equipped with a temperature control and reader, a solenoid flow valve installed in the LPG gas line. Heat distribution is evenly assisted by a 2 inch blower. Drying the peephole takes 4 hours.
\end{abstract}

Key words: Peek, rainy season, production, dryer, $L P G$

\section{PENDAHULUAN}

Intip merupakan makanan tradisional berasal dari nasi, jika menanak nasi dengan menggunakan kendil atau panci, intip atau kerak berada paling bawah. Agak keras dan di dasarnya berwarna hitam karena menerima panas berlebih. Intip adalah makanan cemilan tradisional hasil penggorengan kerak nasi, dan sekarang di Sragen telah banyak usaha intip dengan aneka rasa, kandungan nutrisi intip goreng per 100 gr terkandung sebanyak 474 kkal energi, lemak 21.6 kkal, protein 7.6 kkal. Karbohidrat 62.3 kkal ( Toufik H dkk, 2018).

Intip nasi terbentuk terbentuk karena beras yang di masak untuk diolah menjadi nasi mendapat panas dari didnding kendil atau panci. Tetapi karena kebutuhan sangat tinggi untuk 
makanan, maka beberapa kelompok masyarakat kreatif membuat usaha makanan intip dengan cara merekayasa bentuknya dengan cetakan, dan di beri rasa yang beraneka rasa ada yang rasa manis, asin atau tanpa rasa. Pelung usaha ini juga di tangkap oleh ibu ibu yang tergabung dalam BUMDes "Soyo Ngremboko" desa Gawan Kabupaten Sragen. Produksi saat musim kemarau tidak ada kendala yang berarti, tetapi ketika musim terjadi masalah yaitu terkendala pada pengeringan. Pengeringan masih mengandalkan sinar matahari, terjadi kendala bila hujan terus menerus, intip tidak kering dan akibatnya berjamur.

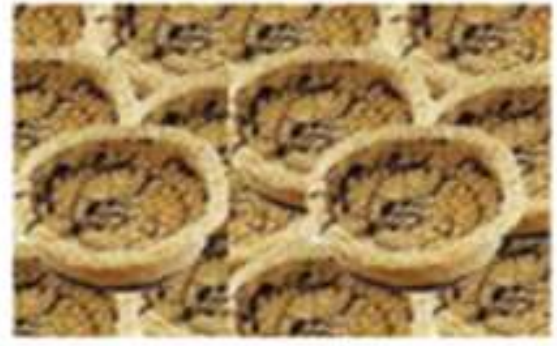

a. Intip cetakan

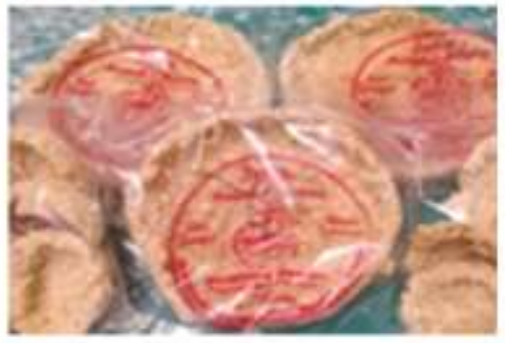

b. Intip khas gawan

Gambar 1 Intip gawan dan intip cetaka produk lain

Solusi yang ditawarkan adalah mesin pengering yang mudah dalam operionalnya dan menggunakan bahan baku yang mudah dalam mencarinya. Mesin pengering berbentuk kabinet, dengan didalamnya dilengakapi dengan loyang berlubang. Panas bersal dari energi panas LPG yang dikontrol dengan control valve yang terhubung dengan thermoreader. Solusi yang ditawarkan berdasarkan studi literatur yang ada. Pengusaha kerupuk puli ketika musim hujan terhambat ketika musim penghujan mengakibatkan produksi merosot hingga $60 \%$, maka diperlukan mesin pengering kerupuk (dryer) (Wardani dkk, 2018). Untuk meningkatkan produktifitas usaha kerupuk menggunakan pengering dengan energi panas dari LPG. Untuk memudahkan sirkulasi konveksi paksa menggunakan sistem rak bertingkat dalam konstruksinya. Konveksi paksa panas yang bersumber dari panas api LPG ke sudut ruang mesin pengering (Fajri dkk, 2017). Pengeringan kerupuk menggunakan mesin pengering berbahan bakar LPG menggunakan sistem konveksi paksa. Hasil dari penggunaan mesin tersebut adalah lebih efisien dalam pengeringan yaitu membutuhkan waktu 4 jam sedangkan dengan sinar matahari butuh waktu 9 jam (Nova dkk, 2017). Penggunaan mesin pengering tipe rak dapat meningkatkan kapabilitas produksi dan menjaga kontinuitas produksi di musim penghujan, sehingga dapat memenuhi permintaan pasar. Pengering menggunakan sistem rak dan konveksi paksa. Panas berasal dari kompor berbahan bakar LPG yang dihembuskan angin lewat blower. Dari mesin yang dibuat mampu mengeringkan kerupuk mencapai kadar air 9\%, dibutuhkan waktu 3 jam. Dapat menghemat waktu, karena jika menggunakan pengering sinar matahari waktu yang dibutuhkan 6 jam (Wignyanto,2015).

\section{METODE}

\section{Pengumpulan data}


Pengumpulan data dengan cara observasi bertanya langsung kepada pengusaha intip, dari studi lapangan studi pustaka. Data tersebut antara lain :

1. Informasi mengenai jumlah dan lokasi pengusaha intip.

2. Permasalahan utama pengusaha intip terutama pada saat musim hujan.

3. Proses produksi dan peralatan yang digunakan.

4. Waktu yang digunakan dalam proses produksi.

5. Mesin pengering intip yang diharapkan oleh UKM.

\section{Solusi yang ditawarkan}

Solusi yang ditawarkan berdasarkan motivasi yang diberikan yaitu :

1. Penerapan teknologi untuk mensiasati ketika ada kendala, terutama ketika musim penghujan, dibutuhkan pengering yang effektif dan tidak merubah rasa intip.

2. Pelatihan penggunaan mesin pengering sehingga dapat memperlancar produksi.

\section{Desain alat pengering}

Berikut tahap pembuatan mesin pengering intip sistem turbulent

1. Prinsip kerja unit pengering intip

2. Perencanaan dan penentuan dimensi mesin pengering, dengan mempertimbangkan keamanan operator, effisiensi mesin pengering dan penentuan bahan bakar

3. Penentuan bahan pembuatan pengering.

4. Estimasi belanja bahan dan barang.

5. Pengerjaan mesin pengering intip

6. Pengukuran, pemotongan pengerjaan permesinan sesuai dengan gambar mesin yang sudah dibuat.

7. Penggabungan komponen dilakukan untuk mengetahui proseskemudahan bongkar pasang konstruksi dan bahan yang digunakan untuk membuat perancangan pengering.

8. Perakitan dari beberapa bagian mesin pengering sesuai dengan gambar perencanaan

9. Uji coba mesin pengering mengenai kerja setiap alat pendukung di mesin pengering.

10. Analisa pengering.

11. Siap digunakan produksi.

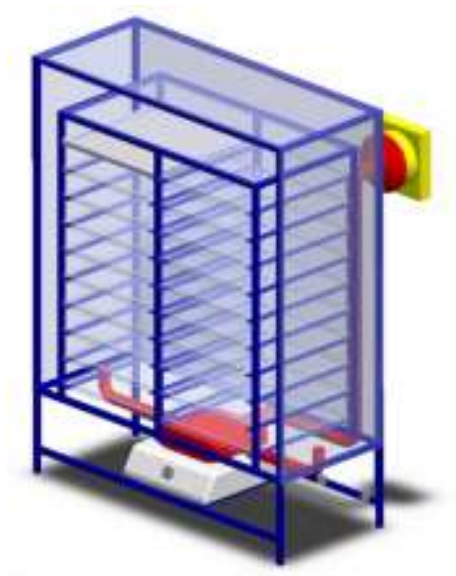

Gambar 2 Perencanaan teknologi yang akan dikembangkan

Gambar 2 menjelaskan mengenai teknologi yang akan dikembangkan berupa mesin pengering bertingkat, jumlah tingkat direncanakan 20 dengan ukuran per loyang/ tempat pengering intip 
$45 \mathrm{~cm} \times 45 \mathrm{~cm} \times 4 \mathrm{~cm}$. Pemanas menggunakan LPG dan diatur gas yang mengelir menggunakan flow gas solenoid. Untuk menghasilkan aliran yang rata di dalam mesin pengering maka di hembuskan udara panas dengan melalui lubang saluran didalam mesin pengering yang saling berhadapan. Harapannya adalah terjadi aliran turbulen di dalam mesin pengering tersebut dan panas menjadi rata di dalam mesin pengering.

\section{Analisa Teknik}

Menganalisa secara cermat mengenai sirkulasi udara panas yang ada di dalam mesin pengering, Fungsi alat bantu yang dipasang, panas yang terbuang dan yang utama adalah pengecekan ketepatan alat ukur temperatur terhadap konsumsi bahan bakar. Mencari titik optimum penggunaan bahan bakar dan penyebaran panas di posisi dalam mesin pengering sesuai perencanaan atau tidak ( Rahmad , 2018).

\section{HASIL DAN PEMBAHASAN}

Perencanaan awal berdasarkan beberapa masukan dan studi literatur yang telah dilakukan menghasilkan unit mesin pengering yang diharapkan merupakan solusi yang tepat untuk membantu UKM intip tetap produksi dimasa penghujan. Disain mesin pemanas tetap memperhatikan nilai keamanan operator dan lingkungan. Sehingga UKM tetap produktif, keresahan selama ini bisa ada solusi yang tepat.

Jarak antara plat dalam dan plat luar $5 \mathrm{~cm}$. Plat dalam dilubangi dengan jarak dan diameter yang sama berfungsi untuk mengalirkan udara panas bersirkulasi didalam mesin pendingin. Panas menggunakan energi LPG, kompor diletakan di bawah, kompor tunggal yang dipasang di tengah. Untuk memaksakan sirkulasi panas di dalam dipasang blower dan udara panas di masukan ke kadalam mesin pemanas.

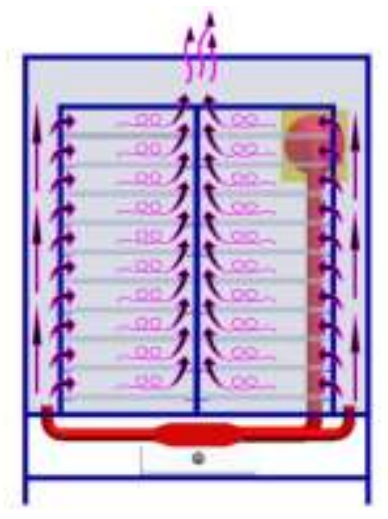

Gambar 3 Penyebaran panas secara turbulent dalam mesin pemanas

Gambar 3 menjelaskan mengenai konveksi paksa yang ada di mesin pengering dan karena tertutup maka arah aliran turbulent. Sirkulasi panas di dalam mesin pengering berasal dari blower. Kontrol temperatur menggunakan thermoreader dan thermocontrol, yang terhubung dengan flow solenoid valve yang berfungsi ketika temperatur didalam ruangan melebihi temperatur yang telah kita setting maka aliran gas menjadi kecil sehingga pembakaran berkurang dan panas akan sesuai dengan temperatur yang telah di atur (B Rachmat, 2018) Dari pengujian yang telah dilakukan panas yang dihasilkan sesuai denga yang diharapkan. Panas tersebut merambat dari kanan kiri mesin api. Kemudian merambat dari atas ke bawah 
sehingga panas yang dicapai sesuai dengan panas sinar matahari dan tidak merusak kultur dari intip

Dari proses pengujian mesin pengering intip yang telah dilakukan mendapatkan hasil yang baik, artinya mesin sudah bisa digunakan untuk mengeringkan intip secara optimal, hasilnya hampir sama dengan pengeringan matahari. Lama pengeringan kurang lebih 4 jam untuk pengeringan $40 \mathrm{~kg}$ intip basah bila sudah dikeringkan berat menjadi $36 \mathrm{~kg}$ intip.

Panas yang dihasilkan dengan cara perambatan panas secara konveksi paksa dengan perambatan yang pelan dan acak sehingga panas yang terabsorb menyebar keseluruh ruangan. Gambar 8 adalah foto mesin pengering yang digunakan untuk mengeringkan intip. Dari pengujian yang telah dilakukan panas yang dihasilkan sesuai denga yang diharapkan.

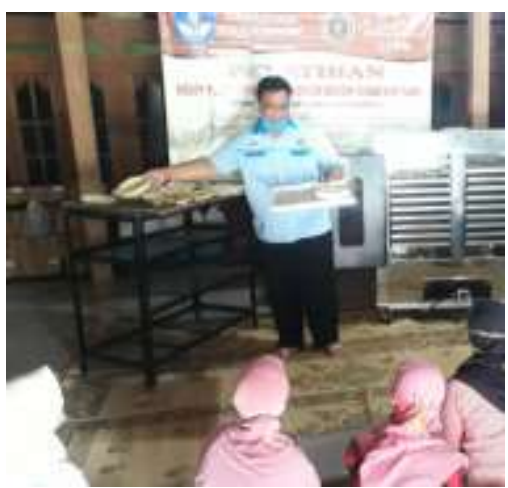

Gambar 4 Pelatihan penggunaan mesin pengering

Panas tersebut merambat dari kanan kiri mesin api. Kemudian merambat dari atas ke bawah sehingga panas yang dicapai sesuai dengan panas sinar matahari dan tidak merusak kultur dari intip. Panas pengering antara $45^{\circ} \mathrm{C}$ sampai dengan $70{ }^{\circ} \mathrm{C}$ dengan demikian membutuhkan waktu yang cukup untuk mengeringkan intip tersebut.

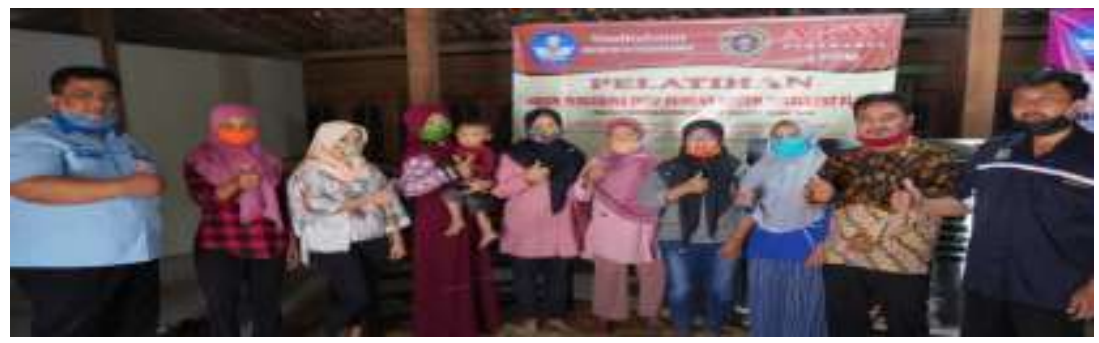

Gambar 5 Kelompok Bumdes Soyo Ngremboko.

Proses pemanasan awal di mesin pengering membutuhkan waktu 20 menit -35 menit setelah panas sudah menyebar pertama digunakan untuk memanaskan ruang, kemudian proses pemanasan sampai kering memerlukan waktu kurang lebih 3-3,5 jam sampai keringnya hampir sama dengan pemanasan dengan sinar matahari.Kapasitas intip kurang lebih satu kali proses produksi adalah $40 \mathrm{~kg}$. Gas LPG sebanyak $3 \mathrm{~kg}$ digunakan untuk 3 kali proses.

\section{KESIMPULAN}

Dari program pengabdian kepada masyarakat dapat diambil kesimpulan : 
1. Dengan mesin pengering ini UKM intip nasi menjadi tidak risau karena pengeringan menggunakan LPG sebagai pemanas dapat menghasilkan intip kering yang sama dengan pengeringan dengan sinar matahari.

2. Mesin pengering berbahan bakar LPG dilengkapi dengan control temperature yang terkonek dengan aliran LPG dengan pemasangan Flow solenoid control dapat menghemat bahan bakar.

3. Tidak diperlukan ketrampilan khusus dalam proses pengeringan intip nasi, karena pengoperasiannya sangat mudah.

4. Aman bagi operator mesin pengering intip nasi, karena sudah direncanakan dari awal bahwa mesin pengering harus mudah dioperasikan, aman bagi operator dan lingkungan.

5. Dengan menggunakan mesin pengering diwaktu musim penghujan dapat memecahkan permasalahan yang dihadapi UKM pengering intip, karena dengan menggunakan pengering tenaga LPG rasa intip tidak berubah sama dengan ketika mengerinkan dengan sinar matahari.

\section{UCAPAN TERIMA KASIH}

1. Ucapan terima kasih diberikan kepada : Direktorat Riset dan Pengabdian Masyarakat, melalui pembiayaan Direktorat Riset dan Pengabdian masyarakat Deputi Bidang Penguatan Riset dan Pengembangan Kementrian Riset dan Teknologi/ Badan Riset dan Inovasi Nasional sesuai dengan kontrak pelaksanaan Program Pengabdian Masyarakat Nomor : 104/SP2H/PPM/DPRM/2020 tanggal 16 maret 2020.

2. Ucapan terima kasih kepada LPPM AT Warga Surakarta yang telah mendukung penuh program pengabdian yang TIM PKM laksanakan.sesuai dengan kontrak no 2032/A/Puslit/ATW/VI/2020 tanggal 11 Juni 2020.

\section{DAFTAR PUSTAKA}

B. Rachmat, E. I. Rhofita, J. T. Mesin, 2016, Rancang bangun alat pengering tipe rak sistem double blower, Pros. Sentia Politek. Negri Malang, vol. 8, pp. 6-10.

E. Y. S. Basuki Widodo,2018, Pemanfaatan Box Pengering Dalam Peningkatan Higienitas produksi kunyit kering di desa wates kecamatan slahung, J. Apl. dan Inov. Ipteks Soliditas, vol. 1, no. 1, pp. 24-28.

Novarini dan Sukadi, 2018, Kinerja Pengering Kerupuk Dengan Sistem Konveksi Paksa,” J. Inov., vol. 1, no. 1, hal. 6-9.

R. P. Fajri, J. P. Putra, Maimuzar, dan Ruzita Sumiati, 2017, Alat Pengering Kerupuk Palembang dengan Menggunakan Gas LPG, Politek. Negri Padang, vol. 10, no. 2, hal. 31-37.

Syarifudin dan Purwanto, D.P. (2009). Oven Pengering Kerupuk Berbasis Mikrokontroler Atmega 8535 Menggunakan Pemanas Pada Industri Rumah Tangga. Jurnal Teknologi IST AKPRIND, vol. 2, 2009

T. Hidayat dan Sutrisno, 2018, Alat Pengering Intip nasi Yang Efisien, J. Litbang Sukowati, vol. 1, hal. 62-69.

T. Wardhani dan F. D. Anggraeni, 2018, Iptek Bagi Masyarakat Kelompok Usaha Krupuk Puli, J. Teknol. pangan, vol. 9, no. 1, hal. 51-58.

Wignyanto dan E. Lestari, 2015,Penerapan Mesin Pengering meknis Untuk Penguatan kapabilitas Produksi Pada Industri ' Kerupuk Kentang' Sebagai Upaya Pemenuhan Permintaan Pasar., J. Innov. Appl. Technol., vol. 1, hal. 75-81 